\title{
Assessing human effects on the Baltic Sea ecosystem
}

\author{
This article belongs to Ambio's 50th Anniversary Collection. Theme: Eutrophication
}

\author{
Ragnar Elmgren
}

Published online: 3 February 2021

\section{BACKGROUND}

I started my research career in 1970 at Stockholm University's field station, the Askö Laboratory, in a research group studying the basic ecosystem ecology of the Baltic Sea. Initially, my research dealt primarily with the soft sediment meiofauna and its relationship to the macrofauna (Elmgren 1978), but I also tried to synthesize the current understanding of the Baltic Sea ecosystem, using data mainly from the 1970s and early 1980s. I did this by calculating carbon flows in the Baltic ecosystem, from primary producers and bacteria to top predators and fisheries yield to humans (Elmgren 1984). The results clearly indicated phytoplankton primary production as the dominant carbon input, except in the Bothnian Bay, where primary production was so low that river input of organic material was almost as large. The Bothnian Bay also stood out in having very low macrobenthos biomass and fisheries yield. The estimated consumption of mesozooplankton and invertebrate macrofauna (except molluscs) by fish was high enough to indicate the possibility of top-down effects.

While pursuing this basic ecological research, I also became engaged in applied research on the effects of human activities in marine ecosystems, starting with oil pollution, during a period at the Marine Ecosystems Research Laboratory, University of Rhode Island. We found that oil-polluted mesocosms developed an algal soup, because the zooplankton and filter feeders that normally kept the phytoplankton in check were more sensitive to oil (Elmgren et al. 1980). While I was still in the US, an opportunity to apply this experience to the Baltic arose with the 1977 Tsesis oil spill near the Askö Laboratory. My Askö colleagues collected data on effects at all levels of the ecosystem, from bacteria to fish, and on my return to Stockholm, they invited me to participate in publishing the results. Satisfyingly, we found evidence in the field of trophic interactions similar to those we had seen in the mesocosms.

In Sweden in the early 1980s, there was growing concern that pollution by plant nutrients was harming the marine environment, but also controversy regarding both the seriousness of the problem, and how to manage it. A colleague and I had published some of the first biological evidence for eutrophication effects in the Baltic Sea, a large increase in macrofauna biomass above the halocline in the Baltic Sea proper since the 1920s (Cederwall and Elmgren 1980). My research had at that time recently been positively evaluated for the Swedish Natural Science Research Council by an international scientific evaluation committee. I presume this was why I was asked to participate in writing a report to the Swedish Environment Protection Board on marine eutrophication research needs. The report was well received and resulted in the major research program "Eutrophication in the Marine Environment". Using data reported by the countries around the Baltic to the Helsinki Commission, my colleague Ulf Larsson led an effort to estimate the nutrient loads on the Baltic Ecosystem. We calculated increases of about fourfold for nitrogen and as much as eightfold for phosphorus in the twentieth century, but with considerable uncertainty (Larsson et al. 1985).

\section{THE FEATURED ARTICLE}

My article in Ambio (1989) marked a fusion of my two previous lines of research, by estimating how Baltic Sea energy flows had changed since the beginning of the twentieth century, due to various and increasing human pressures. This involved estimating both the bottom-up 
effects of increased nutrient inputs, starting with stimulation of the primary production (largely based on results from the research program "Eutrophication in the Marine Environment"), and the top-down effects from the overhunting, fishing and fecundity reduction by toxic pollutants that had decimated populations of Baltic top predators. Discussions with colleagues, several of them my former graduate students, were of great help in this.

As a starting point, I used my estimates of recent energy flows around 1980 (Elmgren 1984), and data on inorganic nutrient increase in Baltic Sea surface water in winter in recent decades. In the Askö-Himmerfjärden area, my colleague Ulf Larsson had found that integrated primary production during the spring bloom was directly proportional to the standing stock of inorganic nitrogen at the start of the bloom. Nitrogen was thus the most limiting nutrient for phytoplankton production in this area. Assuming the same for the whole Baltic allowed a first-order estimate of a 1.8-3-fold increase of the spring bloom. I assumed the summer increase to be somewhat lower, with even less of an increase in autumn production, which was likely to be limited by light rather than nutrients. That the main primary production increase occurred during the spring bloom suggested that the resulting mesozooplankton production increase was probably smaller than that of the phytoplankton primary production, since the mesozooplankton in the Baltic proper hatch late from overwintering eggs, and miss much of the spring bloom. As a result, more primary production sinks to the bottom during the spring bloom than later in the year (Elmgren 1978), which allows production by benthic macrofauna to increase much more than the primary production, except where the increased sedimentation leads to hypoxia killing the fauna.

Fish production depends primarily on the production of zooplankton that are eaten by fish larvae, and by adult zooplanktivorous fish like herring (Clupea harengus), and sprat (Sprattus sprattus). Larger fish eat smaller fish and also benthic fauna, and are in turn eaten by seals, porpoises and humans. Fish catches were less than 100000 tons/ year around 1900, and by mid-1980s had increased to about 850000 tons/year. By then, decimated seal and porpoise populations consumed less than 10000 tons/year of fish, compared to an estimated 320000 tons/year in 1900. The huge increase in fish catches was thus only partly due to higher production, but mostly to more efficient fishing methods (trawling in particular) and the reduction of competing populations of marine mammals.

As I was careful to point out, my calculations were based on mostly rather uncertain estimates. They were still surprisingly well received, however, and the featured article has been cited some 250 times, peaking in $2002^{1}$,

$\overline{1}$ Web of Science July 20, 2020. probably because it provided a review that was lacking. Nevertheless, in retrospect one misses important aspects that were weakly developed or missing, like the microheterotrophic food chain, the top-down effects of overfishing, seabirds as top consumers and the now evident climate change effects.

\section{LATER DEVELOPMENTS}

The year after publication of the featured article, the research program "Eutrophication in the Marine Environment" published its main results in a special issue of Ambio on marine eutrophication (volume 19, issue 3), with a foreword by Scott Nixon. The articles in it were internationally well received and much cited, and the program's recommendations were important in steering Swedish eutrophication management for over a decade. Personally, I was invited to several interesting eutrophication-related workshops where our Baltic experience was wanted (e.g. Howarth et al. 1996).

I have continued to work on the effect of eutrophication on Baltic Sea ecosystems. Modelling (Sandberg et al. 2000) showed that my original estimates (Elmgren 1984) implied that more carbon accumulated in the system than was indicated by measurements, probably because the full trophic complexity of Baltic food webs, such as the microheterotrophic food chain, were not represented in the original publication. I have worked increasingly on the cyanobacterial blooms that are often considered the main eutrophication problem in the Baltic Sea. We used the sediment record to show that the history of cyanobacterial blooms in the Baltic Sea goes thousands of years back (Bianchi et al. 2000), and satellite data to show that cyanobacterial surface accumulations have increased in extent since 1979, and now occur about three weeks earlier in the summer (Kahru and Elmgren 2014). The latter result led to publications on climate change in the Baltic Sea (e.g. Kahru et al. 2016), and its management implications. The long history of Baltic cyanobacterial blooms has been confirmed and covered in detail in several recent publications based on the sediment record.

At the time of writing the featured article, nutrient loads at the beginning of the twentieth century were still thought to be near pristine. Later publications have argued that substantial human stimulation of nutrient loading probably started much earlier, with the growth of agriculture in the drainage basin, and I tend to agree. During the 1980s and early 1990s, it was also generally assumed that the recent rapid increase in nutrient loads to the Baltic Sea was still continuing, adding urgency to the eutrophication problem. Later estimates showed, however, that loads actually peaked around 1985-1990, and have since decrease 
considerably, especially for phosphorus (Gustafsson et al. 2012), but the spread of oxygen-deficient bottom water has still continued well into the 21 st century.

We also discussed the interaction of human-induced trophic cascades and eutrophication in the ecological regime shifts in the Baltic Sea during the last century (Österblom et al. 2007). Since the publication of the featured article, Baltic seal populations have rebounded, as have populations of fish-eating birds, leading to competition for the fish with the fishery (Hansson et al. 2018) and emphasizing the importance of top-down effects in the Baltic Sea.

\section{OUTLOOK FOR THE FUTURE}

In recent years, overviews similar to the featured article have become much more ambitious, usually involving sophisticated Baltic ecosystem modelling to study the combined effects of eutrophication, climate change and fishing, and with often a dozen or more authors. Decisionmakers like such multi-authored papers, since they can be considered to represent the consensus desired as a base for decisions. There is a risk, however, that compromises in the writing conceal real differences of opinion among scientists that if clearly expressed would stimulate research and lead to even better decisions.

\section{REFERENCES}

Bianchi, T.S., P. Westman, C. Rolff, E. Engelhaupt, T. Andrén, and R. Elmgren. 2000. Cyanobacterial blooms in the Baltic Sea: Natural or human-induced? Limnology and Oceanography 45: $716-726$.

Cederwall, H., and R. Elmgren. 1980. Biomass increase of benthic macrofauna demonstrates eutrophication of the Baltic Sea. Ophelia Suppl. 1: 287-304.

Elmgren, R. 1978. Structure and dynamics of Baltic benthos communities, with particular reference to the relationship between macro- and meiofauna. Kieler Meeresforschungen, Sonderheft 4: 1-22.
Elmgren, R. 1984. Trophic dynamics in the enclosed, brackish Baltic Sea. Rapports et Procès-verbaux des Reunions. Conseil International pour l'Exploration de la Mer 183: 152-169.

Elmgren, R. 1989. Man's impact on the ecosystem of the Baltic Sea: Energy flows today and at the turn of the century. Ambio 18: 326-332.

Elmgren, R., G.A. Vargo, J.F. Grassle, J.P. Grassle, D.R. Heinle, G. Langlois, and S.L. Vargo. 1980. Trophic inter-actions in experimental marine ecosystems perturbed by oil. In Microcosms in ecological research, eds. G.P. Giesy Jr, 779-800. U.S. Technical Information Center, U.S. Department of Energy Symp. Ser 52 (CONF-781101).

Gustafsson, B.G., F. Schenk, T. Blenckner, K. Eilola, H.E.M. Meier, B. Müller-Karulis, T. Neumann, T. Ruoho-Airola, et al. 2012. Reconstructing the development of Baltic Sea eutrophication 1850-2006. Ambio 41: 534-548. https://doi.org/10.1007/s13280012-0318-x.

Hansson, S., U. Bergström, E. Bonsdorff, T. Harkonen, N. Jepsen, L. Kautsky, K. Lundstrom, S.G. Lunneryd, et al. 2018. Competition for the fish-fish extraction from the Baltic Sea by humans, aquatic mammals and birds. ICES Journal of Marine Science 75: 999-1008.

Howarth, R.W., G. Billen, D. Swaney, A. Townsend, N. Jaworski, K. Lajtha, J.A. Downing, R. Elmgren, et al. 1996. Regional nitrogen budgets and riverine $\mathrm{N} \& \mathrm{P}$ fluxes for the drainages to the North Atlantic Ocean: Natural and Human influences. Biogeochemistry 35: 75-139.

Kahru, M., and R. Elmgren. 2014. Multi-decadal time series of satellite-detected accumulations of cyanobacteria in the Baltic Sea. Biogeosciences 11: 3619-3633.

Kahru, M., R. Elmgren, and O.P. Savchuk. 2016. Changing seasonality of the Baltic Sea. Biogeosciences 13: 1009-1018.

Larsson, U., R. Elmgren, and F. Wulff. 1985. Eutrophication and the Baltic Sea-Causes and Consequences. Ambio 14: 9-14.

Österblom, H., S. Hansson, U. Larsson, O. Hjerne, F. Wulff, R. Elmgren, and C. Folke. 2007. Human-induced trophic cascades and ecological regime shifts in the Baltic Sea. Ecosystems 10: 877-889.

Sandberg, J., R. Elmgren, and F. Wulff. 2000. Carbon flows in Baltic Sea food webs. A re-evaluation using a mass balance approach. Journal of Marine Systems 25: 249-260.

Publisher's Note Springer Nature remains neutral with regard to jurisdictional claims in published maps and institutional affiliations.

\section{Ragnar Elmgren ( $\square)$}

Address: Department of Ecology, Environment and Plant Sciences, Stockholm University, 10691 Stockholm, Sweden.

e-mail: ragnar.elmgren@su.se 